livestock and fisheries. Over 100 problem areas have been identified for research and development activity.

Under the most recent changes, however, the National Scientific and Technological Council (CNCT) has disappeared. Its duties have been taken over by the State Committee for Science and Technology (CECT), whose head is a member of the Council of Ministers. This committee is the agency in charge of directing, coordinating and supervising the implementation of state and government policy in science and technology. It has to advise the government, prepare science policy, supervise research, establish research centres, and manage the science and technology information system.

The Academy' of Sciences is now classed as an institute that is a central state agency, but its director will not be a member of the Council of Ministers. It has been charged with the drawing up, supervision and implementation of basic research and with being the link with foreign organisation. The various other technical ministries, covering, for example, the chemical industry, and mines and geology, will continue to have their own laboratories and do their own industrially oriented research. The work of all such ministries, however, will be coordinated by the CECT, which will also link up with the Academy of Sciences, the Ministry of Higher Education and the Ministry of Economic Collaboration.

\section{Growing role}

Cubas' international role is now growing; it is unusual to find a country so little endowed with natural resources such a large source of aid. Cuba's aid essentially comes from the technical expertise that is the result of its massive investment in scientific and technological education. The success has been little short of phenomenal, and it is estimated that there are more experts in the developing countries from Cuba than from any other country. But it is well known that Cuba has not achieved this by its own means. Since 1960 it has been drawn into the Soviet orbit; in 1970 the Soviet-Cuban Commission for Economic, Scientific and Technical Cooperation was formed, and in 1972 Cuba joined Comecon Cuban development has been underwritten by the Soviets to the estimated sum of $\$ 5$ billion since 1959 . The full contribution of the Comecon countries is hard to assess, for apart from credits they provided expertise in the early years and also trained Cuban personnel. In 1969 as much as $20 \%$ of the scientific and technical staff engaged in research and development in Cuba were foreign but this manpower assistance declined as the Cuban investments in education began to produce results around 1970 .

An important instrument in Cuba's new international role is the State Committee for Economic Collaboration (formerly the National Commission for Economic, Scientific and Technical Collaboration). In coordination with the State Committee for Science and Technology, it plans and administers foreign technical aid. As the relentless industrialisation drive continues, Cuba's voice is growing more important in the 'North-South' dialogue. Along with India and Yugoslavia she has been one of the leading advocates of greater trade between the underdeveloped countries. For a country that in the next decade expects to be the most industrialised of that group, it sounds like good business. Mexico and Cuba have already designed sugar mills and equipment for sale to the developing nations.

How far Cuba will be able to continue this programme and supply these countries is uncertain. What is certain is that a massive investment in science and technology has meant great political and economic gains. Castro was indeed prophetic: "The future of this country," he said in 1960, "must be the future of men of science."

\section{Feasible, sound and attractive}

$A$ new report on the prospects for solar energy was published last week. Colin Norman reports from Washington

Given sufficient political and economic support, solar energy technologies could supply as much as $40 \%$ of the world's energy needs by the turn of the century, and a startling $75 \%$ by the year 2025 , according to a report published last week by the Worldwatch Institute, a small think-tank concerned with global problems. Such a major shift from fossil fuels to renewable energy resources "would require an unprecendented worldwide commitment of resources and talent", but the social and economic benefits "would far outweigh the costs and difficulties", claims Denis Hayes, who wrote the report*.

Though a multitude of enthusiastic articles and studies have been written

*Energy: The Solar Prospect (Worldwatch Institute, 1776 Mass Avenue NW, Washington DC 20036, \$2). in the past few years to extol the virtues of solar power, the worldwatch report is already attracting considerable attention. For one thing, it was published while the Carter Administration was in the midst of putting together a long-awaited energy policy for the United States, a policy which is expected to place increased emphasis on renewable energy resources. It also breaks new ground in analysing the worldwide potential for solar power, while most other studies have concentrated on solar prospects in a single country. And its upbeat conclusions are also tempered by some realism about the political obstacles along the road to a solar powered world.

Hayes begins by noting that a transition from oil and gas to alternative power sources is inevitable, given the fact that production of oil and gas is expected to peak in the 1980 s and that the price of those fuels is already beginning to increase by leaps and bounds. $\mathrm{He}$ argues that a switch to coal to provide energy needs over the next 50 years would result in "an absolutely intractable problem" of massive increases in atmospheric carbon dioxide, that a switch to nuclear power would require building so many nuclear reactors and recycling so much plutonium that "such a prospect cannot sanely be greeted with equanimity", and that fusion power is a long distance, unproven technology. That leaves the solar options, which Hayes defines as wind, falling water, biomass and direct sunlight.

Though Hayes is quick to acknowledge that most solar technologies are hard put to compete economically with conventional fuels at current prices, he argues that many alternative power sources have environmental costs and hidden subisidies which are not usually included in economic comparisons. As those costs are not internalised and as oil and gas prices spiral upwards, solar energy will become increasingly attractive, Hayes suggests.

Straightforward comparisons between solar power and conventional fuels also neglect an important factor: solar energy is not just more of the same. "Most energy decisions are based on the naive assumption that competing sources are neutral and interchangeable", Hayes notes, but solar technol- 
ogies offer a highly decentralised and flexible power source which, if widely used, would result in a very different world from one powered chiefly by large central generating stations running on coal or nuclear fission. Solar technologies, Hayes argues, "are more compatible than centralised technologies with social equity, freedom and cultural pluralism".

Hayes's basic message, therefore, is that a transition to a solar era "would be technically feasible, economically sound, and environmentally attractive". Furthermore, "the most intriguing aspect of a solar transition might lie in its social and political ramifications". A constant refrain running through Hayes's study is that many relatively unsophisticated solar technologies are already sufficiently developed to be put to use, either alone or in tandem.

On solar heating and cooling, for example, he argues that more attention should be paid to the thermodynamic efficiency of energy production and use, suggesting that it is "surely the height of thermodynamic foolishness" to use a nuclear reactor operating at thousands of degrees to run a water heater to heat bath water to 30 degrees. About a third of the energy now used in the world provides low-temperature heat, which solar collectors can already achieve in many parts of the world, Hayes claims. Moreover, if the lifetime fuels costs are properly counted in economic comparisons, he contends that solar heaters are already able to compete with conventional fuels.

Another promising renewable energy source is small hydroelectric plants which could easily be constructed to serve small villages. Even in the United States, Hayes reckons, there may be a as many as 50,000 potential sites available for hydropower plants as small as half a megawatt. There is also a large and relatively untapped source of energy from the production of methane from animal wastes, ethanol from fermenting plant wastes, and lowgrade heat from biomass, Hayes suggests. A start has, however, been made on some of those technologies, particularly in India and China which are operating a substantial number of methane plants, and Brazil and Australia, where fermentation plants running on sugar cane and eucalyptus wastes are already in production.

As for more sophisticated uses of solar energy, such as large-scale generation of electricity, Hayes argues that although massive solar generating plants would hold considerable environmental advantages over conventional and nuclear power stations, they would also carry some of the disadvantages of inefficiency and centralisation. "A

\section{Recombinant DNA bill proposed}

ThE Carter Administration last week finally proposed legislation to control all recombinant DNA experiments in the United States, after some three weeks of discussions between the Secretary of Health, Education and Welfare (HEW) and officials from the National Institutes of Health (NIH) and the White House. Although the final version of the bill conforms closely to a draft version proposed last month by an interagency task force, it differs in one key respect: it would allow state and local governments to establish controls on the research which are more stringent than the federal regulations.

The bill was formally introduced into the Senate last week by Senator Edward Kennedy, Chairman of the Senate Health Subcommittee which will handle the legislation. Kennedy made clear, however, that he doesn't necessarily agree with every word in the bill and in a statement he outlined a few reservations with the Administration's approach.

The bill would essentially require the Secretary of HEW to establish regulations to control recombinant DNA research in both public and private institutions. He would be required to issue interim regulations within 90 days and a final version within a year, after allowing suitable time for public comments and discussion. The interim regulations, at least, would probably be the guidelines issued last year by NIH. The bill would also require that all facilities housing recombinant DNA experiments be licensed by HEW.

There is also a provision in the bill which would empower $\mathrm{HEW}$ to

sensible energy strategy demands more than the simple-minded substitution of sunlight for uranium," he suggests. Photovoltaic cells, which convert sunlight directly to electricity, have the advantage of providing a decentralised power source which could be used in tandem with other small-scale generators such as windmills, Hayes notes, suggesting that photovoltaics "may offer the most exciting solar electric prospect".

Unfortunately, however, they also have a major disadvantage: their cost is at present prohibitive. Nevertheless, Hayes is optimistic. He notes in his study that the cost of phatovoltaic cells has dropped from $\$ 200,000$ per peak kilowatt in 1959 to about $\$ 13,000$ today. If the trend continues, and if it is helped by economies of scale, Hayes reckons that the cost may drop to as send inspectors into laboratories the ensure that the regulations are being followed and violations could result in a fine of $\$ 5,000$ per day. Particularly serious and wilful flouting of the rules could also result in a prison term, the bill states.

As for the provision allowing state and local governments to set stricter controls than the federal regulations, many scientists are now supporting federal legislation on the grounds that uniform national regulations would be preferable to a patchwork of local controls of varying stringency. The draft version of the Administration's bill would have accomplished that by simply making the federal controls paramount, but the final version would allow the states to add extra controls if they want to. According to Administration sources, the provision was changed so as not to throttle local debate over recombinant DNA but it also bows to the political reality that a move to pre-empt state and local control would be unlikely to be passed by Congress.

The focus of legislative activity has now shifted to Senator Kennedy's Health subcommittee, which held a public hearing last week. One provision which Kennedy may add to the bill is a requirement that the National Commission for the Protection of Human Subjects of Biomedical and Behavioural Research, which has been looking into a variety of biomedical issues for the past two years, be given the task of examining the long-term implications of genetic engineering.

Colin Norman

low as $\$ 500$ per kilowatt by 1985 .

If the transition to a solar era is not made during the next 50 years, Hayes argues, "the roadblocks will have been political, not technical". With massive investments already made in coal and nuclear technologies, and a large gap between future energy supply and demand generally perceived by energy planners, the political roadblocks are formidable, however. President Carter's forthcoming energy policy, which is expected to be announced next week, is likely to provide a boost to both coal and light water reactors, though it is likely to pour some cold water on longer term nuclear plans. As for solar technologies and other renewable resources, it is expected to provide nothing of the support, and certainly nothing of the magnitude which Hayes calls for. 